\title{
THE WALKER CIRCULATION AND ATMOSPHERIC WATER VAPOUR CHARACTERISTICS OVER THE PACIFIC FOR TWO CONTRASTING YEARS
}

\author{
MARY TOSHIE KAYANO, VADLAMUDI BRAHMANANDA RAO AND ANTONIO DIVINO MOURA \\ Instituto de Pesquisas Espaciais, Ministério de Ciência e Tecnologia, CP 515, 12201-São José dos Campos, SP, Brasil \\ Received 11 April 1988 \\ Revised 17 June 1988
}

\begin{abstract}
The Walker circulation for two contrasting years 1983 (ENSO year) and 1984 (non.ENSO year) is determined. Principal changes in the upper level divergence are noted in the western and central Pacific regions. Thus, this part seems to form the principal branch of the Walker circulation, where a reversal takes place during the two contrasting years. Water vapour characteristics of the atmosphere over the western and central Pacific regions are determined using radiosonde data. During the ENSO event of 1983 an unusual accumulation of water vapour over the central Pacific and a depletion of it over the Indonesian region is noted. Further, the correlation coefficient between the SO index and water vapour variation showed significant values. Another aspect of the tropical atmosphere discussed here is the thermodynamic structure and its implications for the development of convection. Our study revealed a spectacular reversal of atmospheric properties such as the upper level divergence, water vapour, and thermodynamic structure during the two contrasting years.
\end{abstract}

KEY WORDS Water vapour content Tropical circulations Thermodynamic structure ENSO

\section{INTRODUCTION}

Due to their influence on global climate, the El Niño-Southern Oscillation (ENSO) events have received much attention in recent years. The most recent ENSO event of 1983 is considered to be the strongest of this century (Rasmusson and Wallace, 1983) and has provided a new impetus to studies of ENSO. Several recent articles have described the development and the associated climatic anomalies of this extraordinary event (Chen, 1983; Krueger, 1983; Quiroz, 1983; Kousky et al., 1984). The development and decay of ENSO events have several interesting and yet unexplored facets. One such feature is the water vapour content and thermodynamic structure of the tropical atmosphere. In this paper we study the Walker circulation, atmospheric water vapour and thermodynamic structure for two contrasting years 1983 and 1984. Rainfall characteristics approximately reversed between these two years. Although parts of these characteristics have been discussed earlier in other papers, the present study brings together many of the features of the tropical atmosphere, a novelty being the discussion on thermodynamic structure during the contrasting years. Our results show a close interconnection between such atmospheric properties as upper level divergence, water vapour, rainfall and thermodynamic structure and the phase of ENSO.

\section{DATA AND METHODOLOGY}

Wind data (monthly means) were obtained from the National Meteorological Center (NMC) tropical grid point data. Wind data are available at $1000,850,700,500,300$, and $200 \mathrm{mb}$ levels. The temperature and rainfall data are obtained from Monthly Climatic Data for the World, US Department of Commerce (1976-1986). Velocity potential $(\chi)$ is computed by relaxation of the $200 \mathrm{mb}$ divergence, which is calculated

using the NMC data. The boundary conditions used are the same as those of Murakami and Unninayar

0899-8418/89/030243-09\$05.00

(C) 1989 by the Royal Meteorological Society 
(1977), except that the southern boundary is extended to $48 \cdot 1^{\circ} \mathrm{S}$. Precipitable water is calculated using the formula:

$$
P_{w}=\frac{1}{g} \int_{p_{\mathbf{T}}}^{p_{0}} q \mathrm{~d} p
$$

where $q$ is the specific humidity, $p_{\mathrm{T}}=300 \mathrm{mb}, p_{0}=1000 \mathrm{mb}$ and $g$ is the acceleration of gravity. In this study we propose to calculate the so-called 'precipitation efficiency' $(P E)$. This might show interesting differences between the contrasting years. Sellers (1965) defined $P E$ as the ratio between mean daily precipitation and the average precipitable water. He suggested that this ratio can be thought of as the fraction of the average moisture overhead which falls as precipitation on an average day. Following Sellers (1965) we write $P E$ as

$$
P E=\frac{P}{n P_{w}} 100 \text { per cent }
$$

where $P$ is the monthly mean precipitation, $P_{w}$ is monthly mean precipitable water and $n$ is the number of days in a month.

To study the thermodynamic structure, we calculated equivalent potential temperature $\left(\theta_{\mathrm{c}}\right)$, in addition to potential temperature $(\theta)$ and saturated equivalent potential temperature $\left(\theta_{\mathrm{e}}^{*}\right)$ using the method given in Simpson (1978).

\section{RESULTS AND DISCUSSION}

\subsection{Walker circulation}

The interannual variation of the east-west circulation is examined through the $200 \mathrm{mb}$ divergent flow. This circulation in the equatorial vertical zonal plane is called the Walker circulation. Velocity potential $(\chi)$ shows the upper branches of thermal circulations such as the Walker circulation (Krishnamurti, 1971). Figures 1 and 2 show the 3-month mean and anomaly fields of $\chi$ for the two periods DJF (December, January, February) 1982-1983 and DJF 1983-1984, respectively. Anomalies are calculated by subtracting the mean of 6 years (1980-1985) from the individual fields. Figures 1a and 2a show the main differences of the atmospheric circulations over the equatorial Pacific. During DJF 1982-1983 divergent flow over the central equatorial Pacific and convergent flow over the Indonesia/Borneo region prevailed, while during DJF 1983-1984 the divergent flow extended through the Indonesia/Borneo region and adjacent oceanic areas.

The contrast in the circulation patterns over the equatorial Pacific between 1983 and 1984 is more evident in the anomalous fields of $\chi$. Figure $1 \mathrm{~b}$ can be compared with the (lower) figure 10 of Rasmusson and Arkin (1985). Both figures show essentially the same features. The convergent flow over the Indonesian region and the divergent flow to the east can be seen. During DJF 1983-1984 the anomaly field of $\chi$ (Figure $2 \mathrm{~b}$ ) was close to the mean (see figure 3 of Rasmusson and Arkin, 1985).

These features are in general agreement with the tropical circulation characteristics discussed by Kayano et al. (1988) with an anomalous Walker circulation during DJF 1982-1983 and the return to normal conditions during DJF 1983-1984. During DJF 1982-1983, rising motion prevailed over the central equatorial Pacific with sinking to the east and west, while at low levels, westerlies occurred in the western Pacific and easterlies in the eastern Pacific. The circulation reversed over the equatorial Pacific and Indonesia/Borneo region during DJF 1983-1984 (Kayano et al., 1988).

The rainfall pattern during DJF 1982-1983 associated with the anomalous atmospheric circulation was such that heavy rainfall occurred over the central Pacific region and relatively dry conditions prevailed over the Indonesia/Borneo region (see Figure 3 for the rainfall at two key stations, Atuona and Singapore). Even in the other regions there is a good agreement between the rising and sinking motion and the rainfall characteristics, as inferred from the outgoing longwave radiation pattern given in Rasmusson and Wallace (1983) and those given in Kayano (1986) for the continental tropics.

The observed upper level divergence pattern is consistent with the contemporary theoretical notions on heat-induced equatorial circulations. Gill (1980) in an elegant analytical study dealing with these type of 


\section{ANOMALY-DJF B3-84}

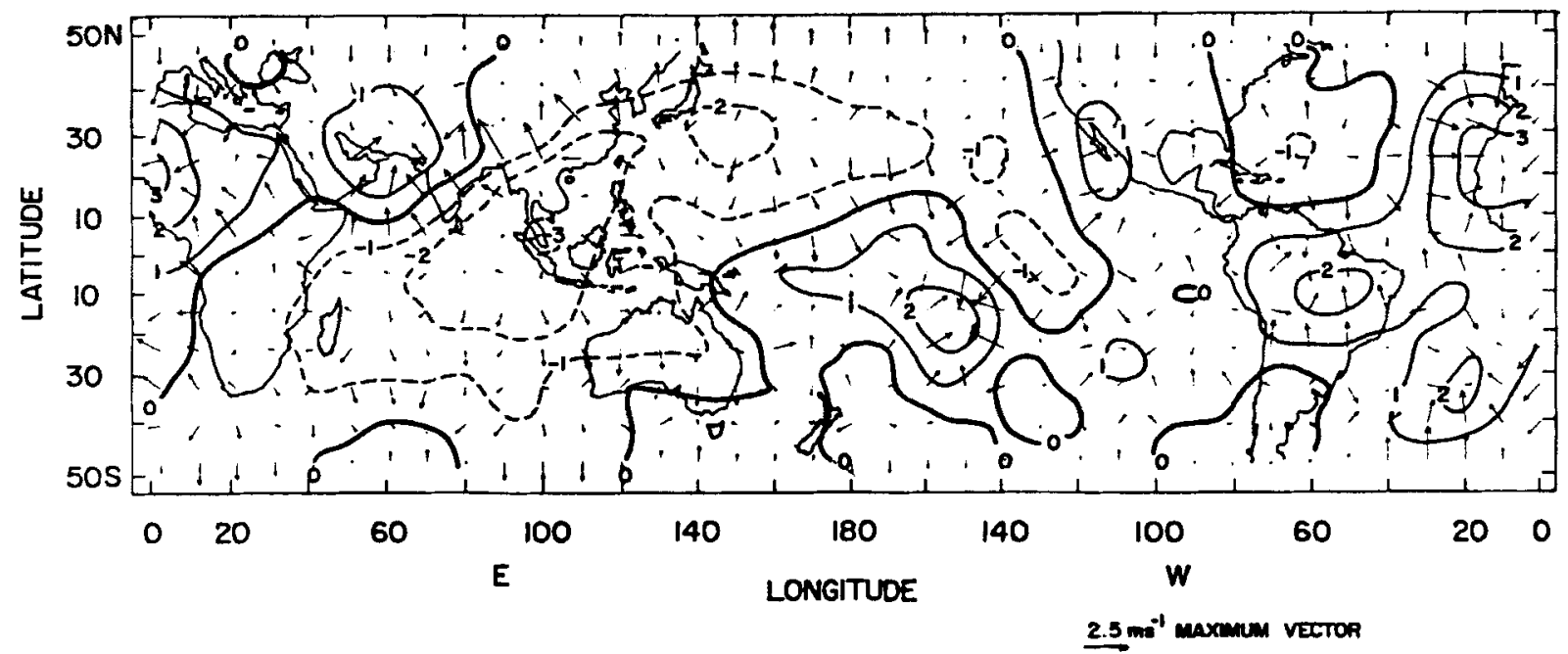

ANOMALY-DFF 82-83

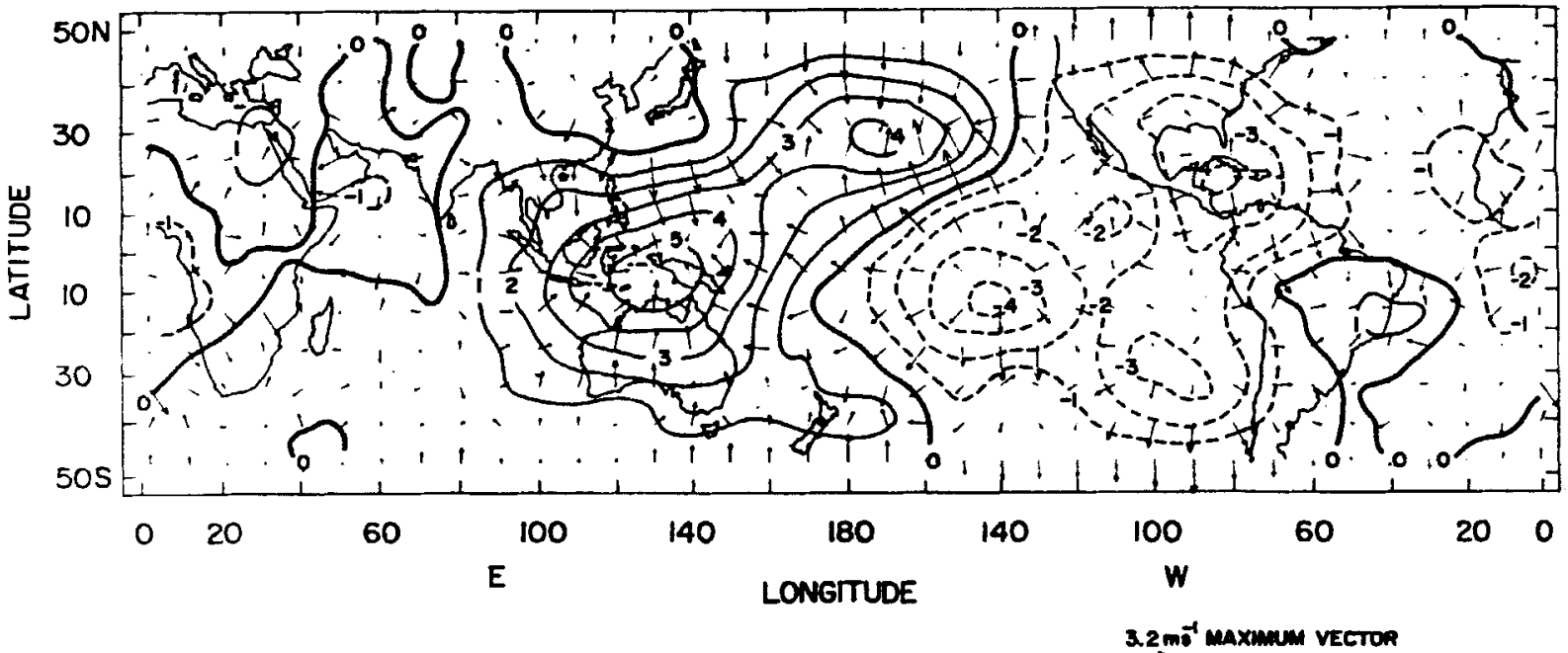

Figure 1. Mean and anomaly fields of velocity potential $\left(10^{6} \mathrm{~m}^{2} \mathrm{~s}^{-1}\right)$ at $200 \mathrm{mb}$ for the 3-month period December 1982 , January and February 1983. Anomalies are calculated by subtracting the mean of 6 years (1980-1985) from the individual fields (contour intervals are $\left.10^{6} \mathrm{~m}^{2} \mathrm{~s}^{-1}\right)$

circulations, showed that rising motion occurs directly above the heat source with easterlies to the east of it and a smaller region of westerlies to the west. He interpreted this pattern in terms of equatorially trapped Kelvin and Rossby waves. When the heating is switched on at an initial time, Kelvin waves travel eastward creating easterlies to the east of the heating. Rossby waves that have a phase speed approximately one-third to that of Kelvin wave speed travel westward. Because of the slower Rossby wave speed the region of westerlies to the west is more limited. Thus, easterlies to the east and westerlies to the west in the lower levels induce convergence and rising motion over the heat source. In the steady state the heating rate is balanced by the adiabatic cooling of the ascent. 


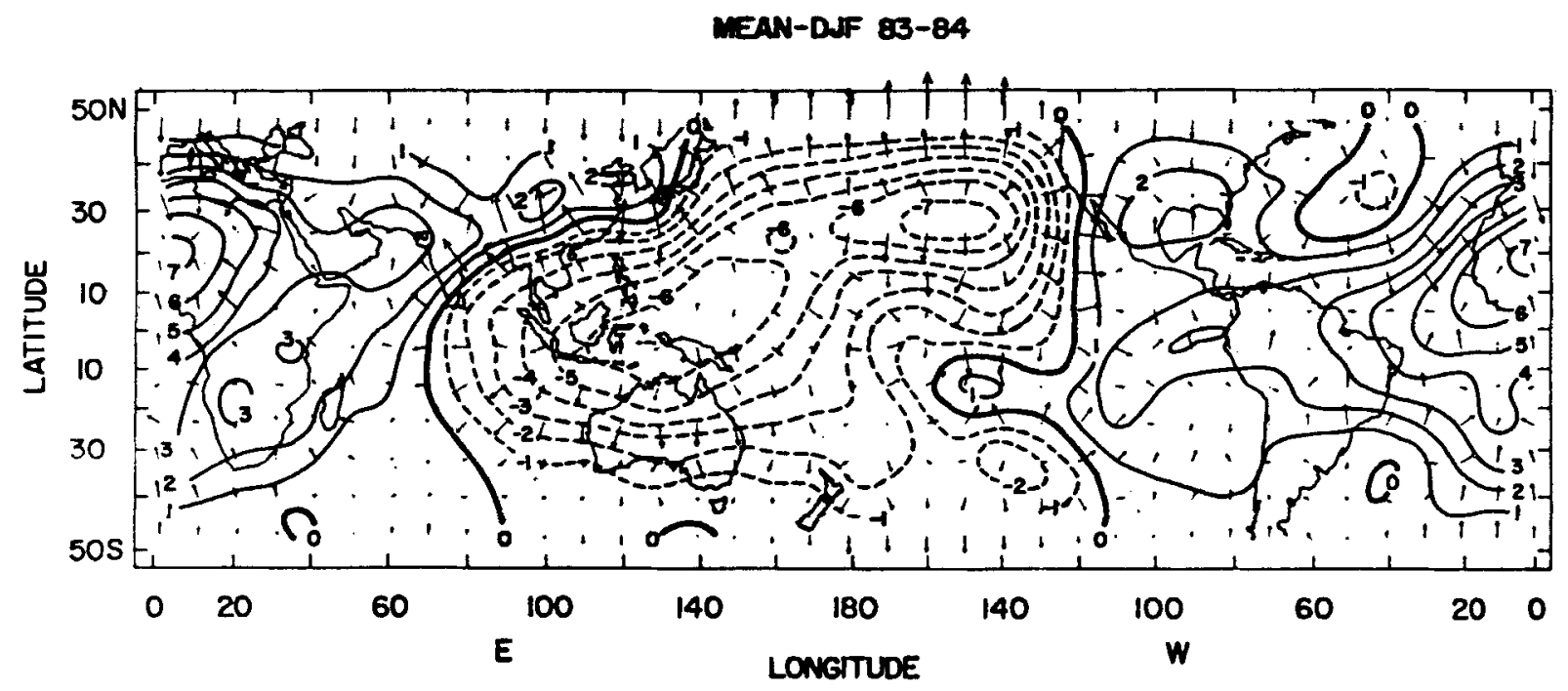

4.7 mis maxman vector

MEAN -DJF 82-83

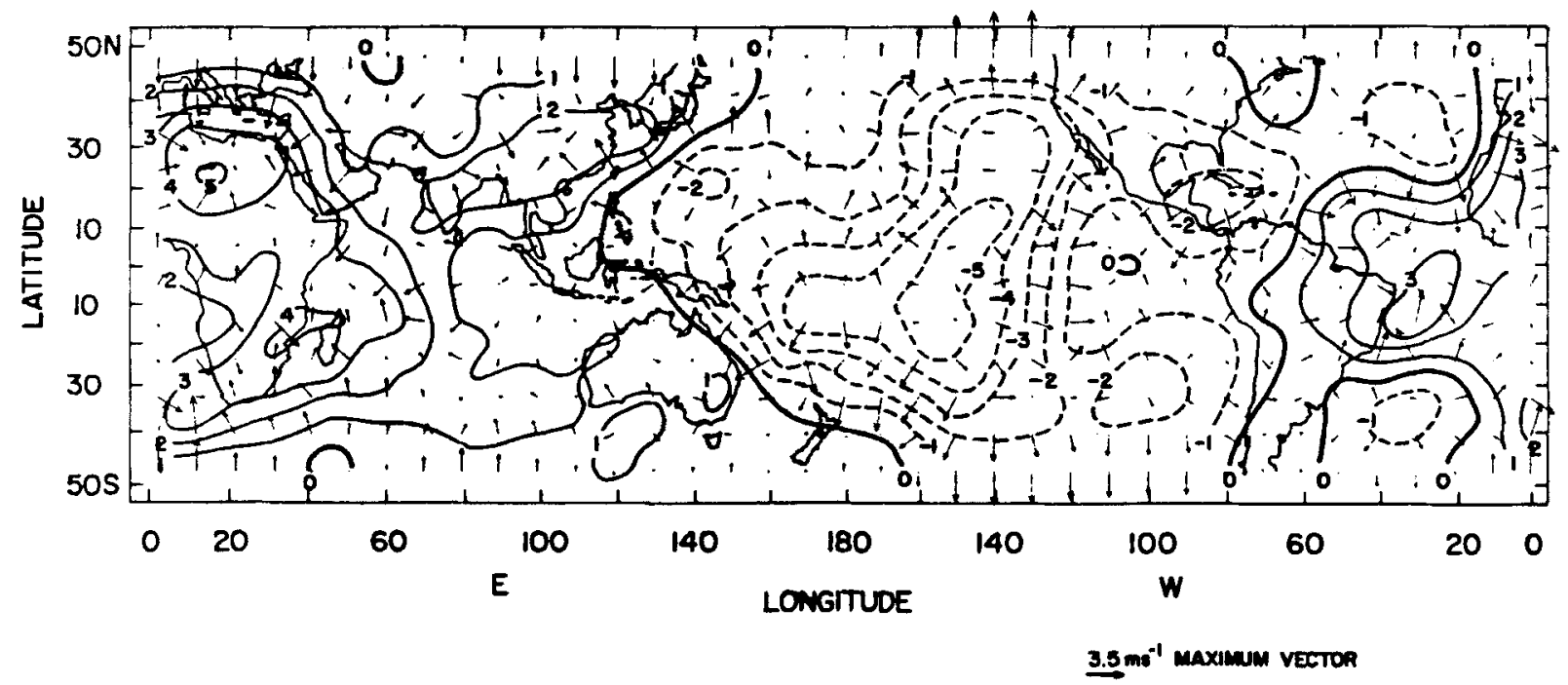

Figure 2. Same as Figure 1 for the 3-month period December 1983, January and February 1984

\subsection{Water vapour and thermodynamic characteristics}

From the earlier discussion it appears that principal changes during the contrasting years (in terms of ENSO) seem to happen in the equatorial Pacific region. So far, the water vapour characteristics and interannual variations in this region have not been examined adequately. Since the variations of water vapour content are essentially controlled by the variations of the low-level convergence or divergence, the variations noted earlier during two contrasting years will have strong implications for the water vapour content. Figure 3 shows the precipitable water $\left(P_{w}\right)$ and rainfall variations for two key stations, Singapore and Atuona. The middle part of the figure shows the monthly mean values of $P_{w}$, while the corresponding monthly rainfall totals are shown in 

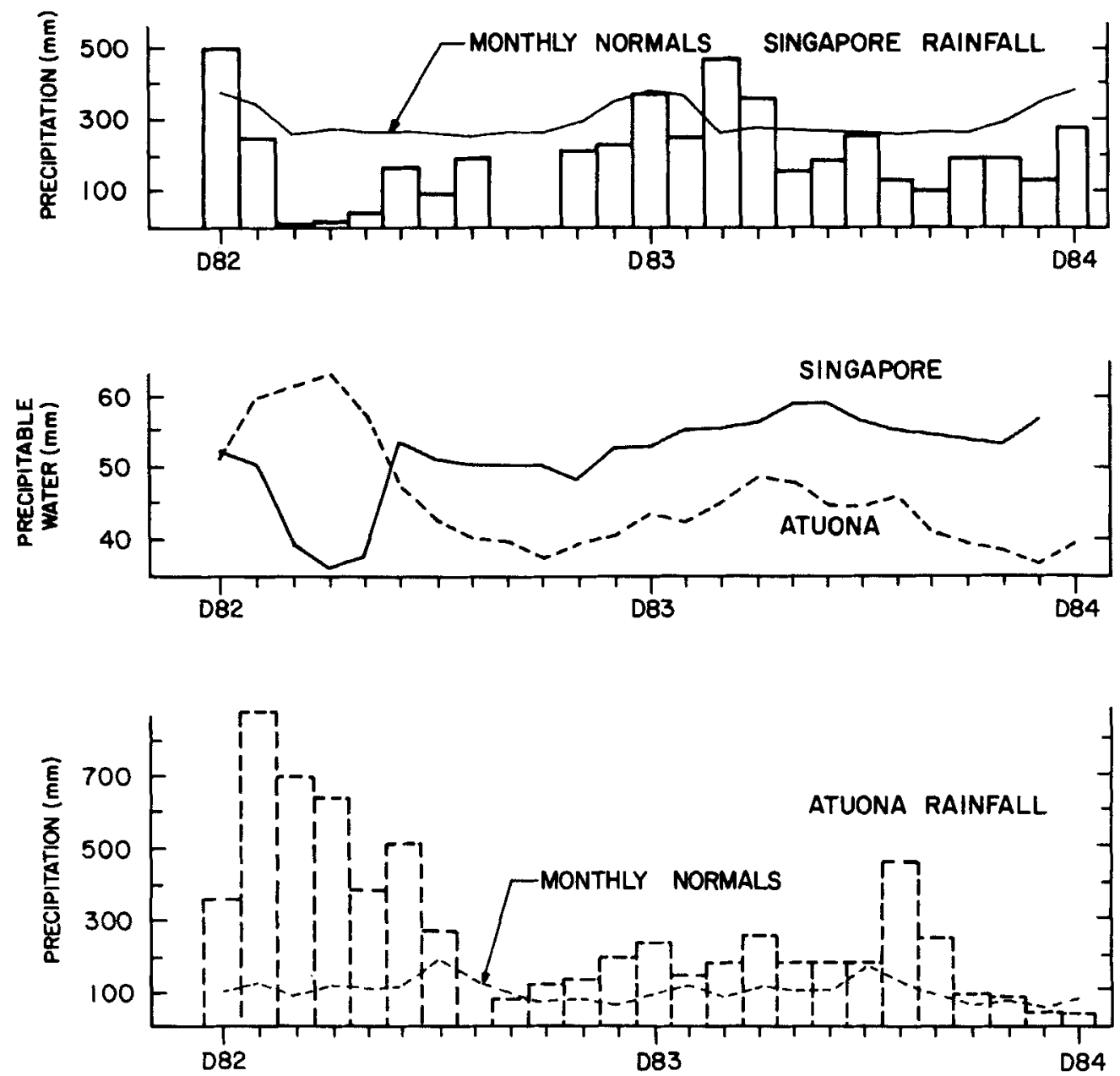

Figure 3. Monthly means of precipitable water (mm) and the corresponding monthly rainfall (mm) totals for Atuona and Singapore. December 1982 (D82) to December 1984 (D84). In the top and bottom figures the monthly normals (long-term means) are shown as continuous and broken lines, respectively. Data for August and September 1983 at Singapore and for July 1983 at Atuona were missing. Continuous lines = Singapore; broken lines = Atuona

upper and lower diagrams as bar graphs for the period December 1982 to December 1984. These two stations are selected such that they represent the rising and sinking limbs of the principal cell of the Walker circulation.

The most important aspect shown in Figure 3 is the marked precipitable water and rainfall changes varying inversely at the two stations during the first half of 1983 . Note in the upper and lower parts of Figure 3, the unusually very high rainfall over Atuona and lack of it over Singapore. During the month of February, Atuona recorded $883 \mathrm{~mm}$ compared to the normal of $87 \mathrm{~mm}$ and Singapore recorded a meagre $6 \mathrm{~mm}$ compared to the normal of $164 \mathrm{~mm}$ ! These features are certainly related to the rising and sinking motions associated with the Walker circulation discussed earlier. Most of the time the water vapour content in the atmosphere over Singapore was more than that over Atuona, but during the first half of 1983 the situation reversed. During March 1983, the difference in precipitable water of the two stations (Singapore minus Atuona) was $-26.85 \mathrm{~mm}$, compared to a mean difference of $5.98 \mathrm{~mm}$ ! The linear correlation coefficient between the two time series is -0.62 , which is significant at the 99 per cent level.

The decrease of rainfall at Singapore from December 1982 up to April 1983 was associated with a decrease of water vapour content and the higher rainfall during this time at Atuona was associated with a rise of water vapour content. Cornejo-Garrido and Stone (1977) suggested that enhanced condensation in the rising 
branch of normal Walker circulation (during a non-ENSO period) is a consequence of water vapour convergence, not enhanced evaporation. Even during an ENSO event this seems to be true. The higher water vapour content over Atuona during the beginning of 1983 was probably due to water vapour convergence in the lower atmosphere, associated with easterlies to the east and westerlies to the west. The theoretical implications for the creation of these easterlies and westerlies have already been interpreted earlier in terms of equatorially trapped Kelvin and Rossby waves. Somewhat similar conclusions have been reached in a recent study (Prabhakara et al., 1985) using satellite inferred water vapour content. However, our results give additional information of the extraordinary ENSO event of 1983, particularly the thermodynamic structure over the tropical Pacific, which will be discussed later in this paper. Further, it is necessary to supplement studies with remotely sensed data wherever possible with data measured 'in situ', such as the radiosonde data.

In order to clarify how the water vapour variations are linked to the Southern Oscillation (SO), we computed for eight key radiosonde stations, the linear correlation coefficient between their $\boldsymbol{P}_{w}$ time-series and the SO index for two periods (January 1983 to December 1984 and January 1976 to February 1986) (Table I). In the latter series, deviations from the monthly means are used to calculate the correlations. The first four stations in Table $\mathbf{I}$, in the equatorial Pacific, are negatively correlated with the SO index, while the last four stations, in the Indonesia/Borneo region, are positively correlated with the SO index. For the 2-year period (1983-1984) all the values except the one for Tahiti are significant at the 99.9 per cent level, and for the longer period (1976-1986) the significance of the correlation coefficient continued to be at the 99.9 per cent level for many stations. This shows a spatial and temporal consistency in the behaviour of the atmospheric water vapour as a response to the SO.

Table II shows the rainfall, $P_{w}$ and $P E$ for the two key stations, Singapore and Atuona. Parameter $P E$ is calculated using equation (2). Note that in Table II, $P E$ was 47.6 per cent in January 1983 at Atuona and

Table I. Correlation coefficient between precipitable water and SO index. Correlation coefficients are calculated with 5-month running means. The SO index (normalized sea-level pressure (NSPL) at Tahiti minus NSPL at Darwin) series are taken from Climate Diagnostics Bulletin,

March 1986, Climatic Analysis Center, National Meteorological Genter, Washington

\begin{tabular}{|c|c|c|}
\hline Station/location & 1983-1984 & $1976-1986$ \\
\hline Tarawa $\left(01^{\circ} 21^{\prime} \mathrm{N}, 172^{\circ} 55^{\prime} \mathrm{E}\right)$ & $-0.81 * *$ & $-0.57 * *$ \\
\hline Funafuti $\left(08^{\circ} 31^{\prime} \mathrm{S}, 179^{\circ} 13^{\prime} \mathrm{E}\right)$ & $-0 \cdot 73^{* *}$ & $-0 \cdot 59 * *$ \\
\hline Atuona $\left(09^{\circ} 48^{\prime} \mathrm{S}, 139^{\circ} 02^{\prime} \mathrm{W}\right)$ & $-0.86^{* *}$ & $-0 \cdot 58 * *$ \\
\hline Tahiti $\left(17^{\circ} 33^{\prime} \mathrm{S}, 149^{\circ} 34^{\prime} \mathrm{W}\right)$ & -0.09 & $-0 \cdot 12$ \\
\hline Singapore $\left(01^{\circ} 22^{\prime} \mathrm{N}, 103^{\circ} 55^{\prime} \mathrm{E}\right)$ & $0.90 * *$ & $0 \cdot 46^{* *}$ \\
\hline Kota Bharu $\left(06^{\circ} 10^{\prime} \mathrm{N}, 102^{\circ} 17^{\prime} \mathrm{E}\right)$ & $0 \cdot 64 * *$ & $0 \cdot 46^{* *}$ \\
\hline Kuala Lumpur $\left(03^{\circ} 07^{\prime} \mathrm{N}, 101^{\circ} 33^{\prime} \mathrm{E}\right)$ & $0.75^{* *}$ & $0 \cdot 19$ \\
\hline Kuantan $\left(03^{\circ} 47^{\prime} \mathrm{N}, 103^{\circ} 13^{\prime} \mathrm{E}\right)$ & $0 \cdot 67 * *$ & $0-27^{*}$ \\
\hline
\end{tabular}

** Significant at 99.9 per cent level.

* Significant at 99.0 per cent level.

Table II. Precipitation, precipitable water, and precipitation efficiencies for Singapore and Atuona

\begin{tabular}{|c|c|c|c|c|c|c|c|}
\hline & & \multicolumn{2}{|c|}{ Precipitation (mm) } & \multicolumn{2}{|c|}{ Precipitable water $(\mathrm{mm})$} & \multicolumn{2}{|c|}{ Efficiency (\%) } \\
\hline & & Singapore & Atuona & Singapore & Atuona & Singapore & Atuona \\
\hline \multirow[t]{3}{*}{1983} & Jan. & 246 & 883 & $50 \cdot 9$ & $59 \cdot 8$ & $15 \cdot 6$ & $47 \cdot 6$ \\
\hline & Feb. & 6 & 702 & $39 \cdot 5$ & $61 \cdot 4$ & 0.5 & 40.8 \\
\hline & Mar. & 19 & 644 & $36 \cdot 4$ & $63 \cdot 2$ & 1.7 & $32 \cdot 9$ \\
\hline \multirow[t]{3}{*}{1984} & Jan. & 251 & 152 & $55 \cdot 5$ & $44 \cdot 8$ & $14 \cdot 6$ & $11 \cdot 5$ \\
\hline & Feb. & 470 & 188 & $55 \cdot 7$ & $45 \cdot 6$ & $30 \cdot 1$ & $14 \cdot 7$ \\
\hline & Mar. & 361 & 264 & $56 \cdot 7$ & $49 \cdot 2$ & $20 \cdot 5$ & $17 \cdot 3$ \\
\hline
\end{tabular}


reduced to 11.5 per cent in January 1984 . However, at Singapore it was a mere 0.5 per cent in February 1983 and increased to 30.1 per cent in February 1984. Thus, precipitation-producing processes were efficient at Atuona and very inefficient at Singapore in the beginning of 1983 and the reverse happened during 1984 at these two stations. In general, precipitable water variations are small compared to the rainfall variations. However, during the ENSO event of 1983, precipitable water showed large changes, as noted earlier.

Furthermore, we have analysed the precipitable water variations during 1983-1984 for other radiosonde stations of near-equatorial South America and Africa. However, none showed such contrasting and consistent changes as those seen earlier over the western and central equatorial Pacific areas. So we conclude that the principal limbs of the Walker circulation are those over the central equatorial Pacific and Indonesia/Borneo region.

Another interesting aspect of the equatorial atmosphere related to the ascending and descending branches of the Walker circulation is the thermodynamic vertical structure during 1983-1984. Figure 4 shows the vertical profile of potential temperature $(\theta)$, equivalent potential temperature $\left(\theta_{\mathrm{e}}\right)$ and the saturated equivalent potential temperature $\left(\theta_{\mathrm{e}}^{*}\right)$ the environment would have if it is isothermally brought to saturation. These profiles for Atuona and Singapore are shown for March 1983 and March 1984. The importance of the thermodynamic properties of the tropical atmosphere lies in the fact that tropical precipitation is essentially of convective origin. Typical tropical profiles and the methodology for inferring convection are given in Holton (1979). The differences between the profiles of March 1983 and 1984 over Singapore are striking. The proximity of $\theta_{\mathrm{e}}$ and $\theta_{\mathrm{e}}^{*}$ during March 1984 shows that the atmosphere was very humid. The more uniform profile of $\theta_{\mathrm{e}}$ is due to strong convection and vertical mixing favoured by the large-scale ascending motion (Aspliden, 1976). The layer of conditional instability was deep and favourable for deep convection during March 1984. During March 1983, however, the atmosphere over Singapore was very dry and the layer of conditional instability was also shallow. A careful comparison between $\theta$ profiles of 1983 and 1984 shows that the $\theta$ values are, in general, higher during March 1983, as expected because of the large-scale sinking motion. Almost reverse conditions prevailed over Atuona, with profiles of $\theta_{\mathrm{e}}$ and $\theta_{\mathrm{e}}^{*}$ over Atuona (Singapore) during March 1983 looking like those of Singapore (Atuona) during March 1984.

The profiles of $\theta, \theta_{\mathrm{e}}$ and $\theta_{\mathrm{e}}^{*}$ show some interesting differences in the planetary boundary layer (PBL), but detailed analysis is not possible because of the low resolution of these profiles in the PBL. Nevertheless, some general features can be inferred. It can be seen that over Atuona, the $\theta$ profile is somewhat uniform between $1000 \mathrm{mb}$ and $850 \mathrm{mb}$, while over Singapore it increased with height. These and other differences noted below are probably due to the hour of observation. The hour of observation at both the stations was 00 GMT, which means approximately 15:00 h local time at Atuona and 07:00 h local time at Singapore. Thus, the mixed layer was well established at 15:00 h over Atuona and over Singapore it was probably destroyed at 07:00 h. Further, note that the atmosphere at $1000 \mathrm{mb}$ over Atuona was dry as inferred by the large difference between $\theta_{\mathrm{e}}$ and $\theta_{\mathrm{e}}^{*}$, while at Singapore the difference was much less. We noted these differences in almost all the months we analysed. Further, temperature observations show that the $1000 \mathrm{mb}$ temperatures at Atuona were always higher than at Singapore with the reverse being true at $700 \mathrm{mb}$. These observations suggest that the PBL of Atuona was always characterized by a mechanism which causes a rise of temperature and a decrease of humidity. Such a mechanism is possibly downdraughts in the near-surface layers. Fitzjarrald and Garstang (1981) discussed the vertical structure of the tropical boundary layer and noted the importance of the downdraughts. Further studies, using data with better resolution, are necessary to make detailed analysis of the PBL during the contrasting years.

\section{SUMMARY AND CONCLUDING REMARKS}

The Walker circulation is determined for two contrasting years, 1983 and 1984 . The year 1983 was characterized by a strong ENSO event and 1984 was a non-ENSO year. The general features of the Walker circulation for the two contrasting years, as inferred by the characteristics of mean and anomaly fields of the velocity potential $(\chi)$ at the $200 \mathrm{mb}$ level, are consistent with the vertical velocity field shown by Kayano et al. (1988). The principal changes in upper level convergence and divergence during the two contrasting years 

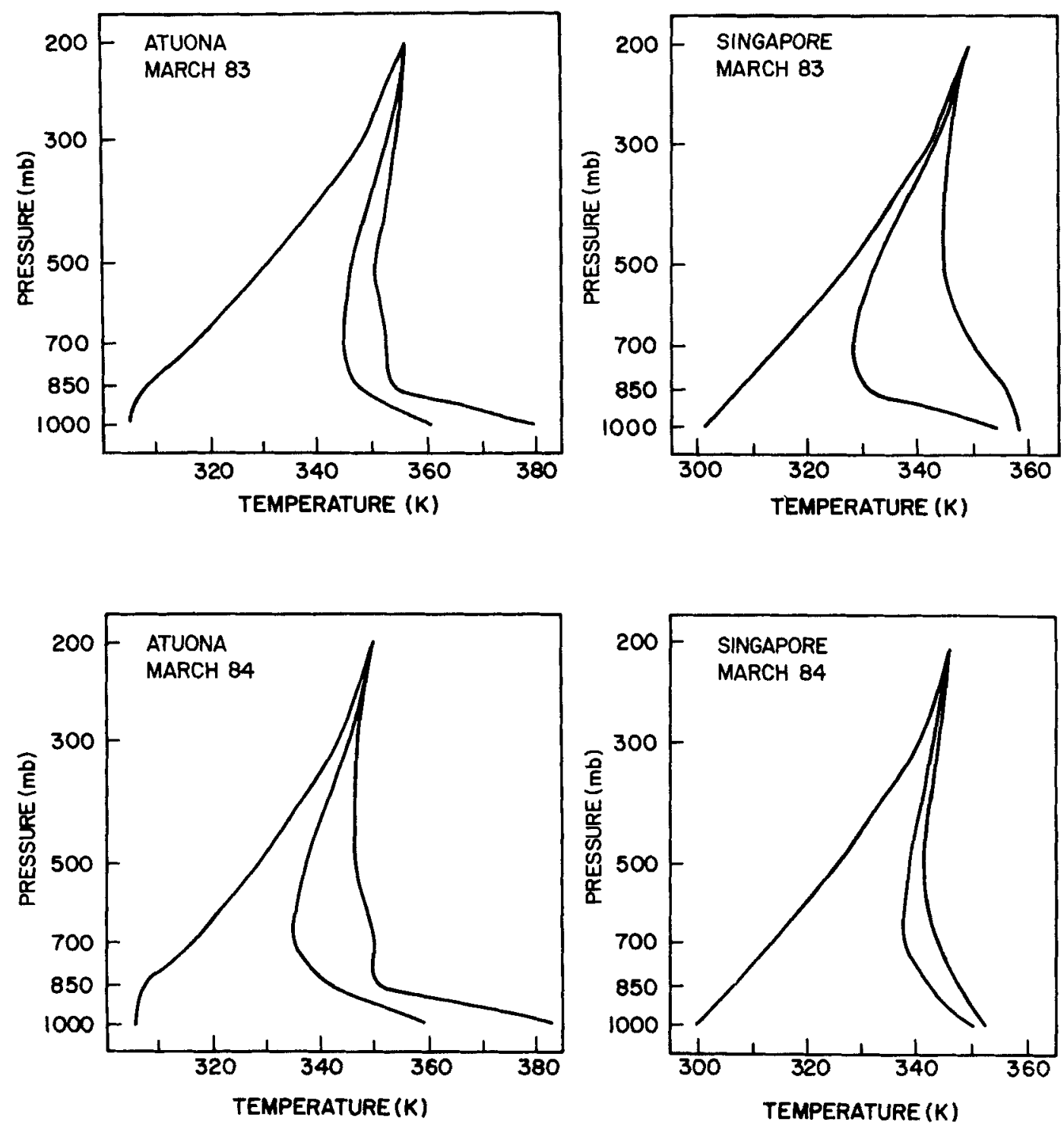

Figure 4. Vertical profiles of potential temperature $(\theta)$, equivalent potential temperature $\left(\theta_{\mathrm{e}}\right)$, and saturated equivalent potential temperature $\left(\theta_{e}^{*}\right)$ for March 1983 and March 1984 at Atuona and Singapore. In these figures all curves at extreme left are $\theta$, then followed by $\theta_{e}$, and $\theta_{e}^{*}$

happened in the western and central Pacific. Thus, this part of the Walker circulation forms the principal cell where major changes take place.

We calculated water vapour characteristics for two groups of four radiosonde stations, each representing the two limbs of the main cell of the Walker circulation in the Pacific. The variations during the two contrasting years showed accumulation of water vapour in the central Pacific and depletion of it in the Indonesian region. Further, the calculation of correlation coefficients between water vapour and the SO index showed highly significant (at 99.9 per cent level) values.

A novel feature of the present study is the discussion of the thermodynamic structure of the principal Walker circulation branch in the Pacific during the two contrasting years. The vertical profiles of $\theta, \theta_{e}$, and $\theta_{e}^{*}$ showed striking differences over the rising and sinking limbs of the Pacific Walker circulation between 1983 
and 1984. The vertical structure of these profiles is interpreted in terms of conditions favourable or unfavourable for the development of tropical convection and precipitation. Further, although the vertical resolution of the profiles is low, some inferences could be drawn regarding the PBL. Thus, in summary, our results show a spectacular reversal of atmospheric properties, such as upper level divergence, water vapour, and thermodynamic structure, between the two contrasting years.

An interesting aspect of the Walker circulation is the mechanism which maintains it. In addition, the heat balance of the Walker circulation forms a curious problem. These aspects are currently being investigated.

\section{ACKNOWLEDGEMENTS}

This paper is taken from the doctoral thesis of the first author. Thanks are due to José P. Bonatti for going through the manuscript.

\section{REFERENCES}

Aspliden, C. I. 1976. 'A classification of the structure of the tropical atmosphere and related energy fluxes', J. Appl. Meteorol., 15, 692-697. Chen, W. Y. 1983. 'The climate of spring 1983-A season with persistent global anomalies associated with El Niño', Mon. Wea. Rev., 111, 2371-2384.

Cornejo-Garrido, A. G. and Stone, P. H. 1977. 'On the heat balance of the Walker circulation'., J. Atmos. Sci., 34, $1155-1162$.

Fitzjarrald, D. R. and Garstang, M. 1981. 'Vertical structure of the tropical boundary layer', Mon. Wea. Rev., $109,1512-1526$.

Gill, A. E. 1980. 'Some simple solutions for heat-induced tropical circulation', Q. J. R. Meteorol. Soc., 112, 69-91.

Holton, J. R. 1979. An Introduction to Dynamic Meteorology, 2nd edn, Washington Academic Press, University of Washington, Seattle, $391 \mathrm{pp}$.

Kayano, M. T. 1986. 'Variacões das circulacões tropicais e as anomalias de precipitacão associadas, em dois anos de contraste' (Variations in the tropical circulations and precipitation anomalies during two contrasting years), Ph.D. thesis, São José dos Campos SP, Brazil, 140 pp. (Available from Instituto de Pesquisas Espaciais, INPE, CP. 515, 12201, São José dos Campos, SP, Brazil.)

Kayano, M. T., Rao, V. B. and Moura, A. D. 1988. "Tropical circulation and the associated rainfall anomalies during two contrasting years', J. Climatol. 8, 477-488.

Kousky, V. E., Kagano, M. T. and Cavalcanti, I. F. A. 1984, 'A review of the Southern Oscillation: oceanic-atmospheric circulation changes and related rainfall anomalies', Tellus, 36A, 490-504.

Krishnamurti, T. N. 1971. 'Tropical east-west circulation during the Northern summer', J. Atmos. Sci., 28, $1342-1347$.

Krueger, A. F. 1983. 'The climate of autumn 1982-With a discussion of the major tropical Pacific anomaly', Mon. Wea. Rev., 111, 1103-1118.

Murakami, T. and Unninayar, M. S. 1977. 'Atmospheric circulation during December 1970 through February 1971', Mon. Wea. Rev., 105, $1024-1038$.

Prabhakara, C., Short, D. A. and Vollmer, B. E. 1985. 'El Niño and atmospheric water vapor: observations from Nimbus 7SMMR', J. Clim. Appl. Meteorol., 24, 1311-1324.

Quiroz, R. S. 1983. 'The climate of the El Niño winter of 1982-83-A season of extraordinary climatic anomalies', Mon. Wea. Rev., 111, 354-384.

Rasmusson, E. M. and Arkin, P. A. 1985. 'Interannual climate variability associated with the E] Niño/Southern Oscillation', in Nihoul, J. C. J. (ed.), Coupled Ocean-Atmosphere Models, Elsevier, Amsterdam, pp. 697-723.

Rasmusson, E. M. and Wallace, J. M. 1983. 'Meteorological aspects of the El Niño/Southern Oscillation', Science, 222, $1195-1202$.

Sellers, W. D. 1965. Physical Climatology, The University of Chicago Press, Chicago, 272 pp.

Simpson, R. H. 1978. 'On the computation of equivalent potential temperature', Mon. Wea. Rev., 106, 124-130. 